17. McGavin CR, Gupta SP, Lloyd EL, McHardy GJ (1977) Physical rehabilitation for the chronic bronchitic: results of a controlled trial of exercises in the home. Thorax 32:307-311

18. Nord E (1993) Toward quality assurance in QALY calculations. Int J Technol Assess Health Care 9:37-45

19. Olsen JA (1993)" “On what basis should health be discounted?"J Health Econ 12:39-53

20. Olsen JA (1993) Time preferences for health gains: an empirical investigation. Health Econ 2:257-265

21. Olsen JA (1994) Persons vs years: two ways of eliciting implicit weights. Health Econ 3:39-46

22. Olson M, Bailey MJ (1981) Positive time preference.J Political Econ 89:1-25

23. Quanjer PH (ed) (1983) Standardized lung function testing. Report working party for standardization of lung function tests. European Community for Coal and Steel, Luxembourg. Bull Eur Physiopathol Respir 19 Suppl 5:1-95

24. Pol MM van der, Cairns JA (2000) Negative and zero time preference for health. Health Econ 9:171-175

25. Redelmeier DA, Heller DN (1993) Time preference in medical decision making and cost-effectiveness analysis. Med Decis Making 13:212-217

26. Shepard DS, Thompson MS (1979) First principles of cost-effectiveness analysis in health. Public Health Rep 94:535-543

27. Stavem K (1999) Reliability, validity and responsiveness of two multiattribute utility measures in patients with chronic obstructive pulmonary disease. Qual Life Res 8:45-54

28. Stavem K, Boe J, Erikssen J (1999) Health status, dyspnea, lung function and exercise capacity in patients with chronic obstructive pulmonary disease. Int J Tuberc Lung Dis 3:920-926

29. Sutherland $\mathrm{HJ}$, Llewellyn-Thomas $\mathrm{H}$, Boyd $\mathrm{NF}_{\text {, }}$ Till JE (1982) Attitudes toward quality of survival."The concept of maximal endurable time." Med Decis Making 2:299-309

30. Torrance GW, Thomas WH, Sackett DL (1972) A utility maximization model for evaluation of health care programs. Health Serv Res 7:118-133

31. Weinstein MC, Stason WB (1977) Foundations of cost-effectiveness analysis for health and medical practices. N Engl J Med 296:716-721
DOI 10.1007/s10198-002-0108-7

H. Sigmund · F. B. Kristensen

Danish Centre for Evaluation and Health Technology Assessment, Copenhagen

\section{Does health technology assessment benefit health services and politics?}

\section{The experiences of an established HTA institution: the Danish Centre for Evaluation and HTA}

In the original publication of this article, Figure 2 was unfortunately wrong printed. We apologize for this mistake. The correct version of Figure 2 can be seen below.

\section{DACEHTA's Organisation}

\author{
Ministry of Health \\ National Board of Health \\ Chief Medical Officer \\ Centre for Evaluation and \\ Health technology Assessment
}

Centre Board

Scientific Board

C) Springer-Verlag 2002

Helga Sigmund

Danish Centre for Evaluation and Health Technology Assessment, National Board of Health, Islands Brygge 67, P.0.Box 1881,2300 Copenhagen S, Denmark, e-mail: hsi@sst.dk 